\title{
Mateusz Gaze
}

Uniwersytet Łódzki

\section{JĘZYKOWY OBRAZ WIELOKULTUROWOŚCI}

SŁOWA KLUCZOWE: językowy obraz świata, kategoryzacja, wielokulturowość, stereotypy

Celem niniejszej pracy jest zbadanie językowego obrazu wielokulturowości we współczesnej polszczyźnie. Chcąc naszkicować językowy obraz jakiegokolwiek pojęcia, trzeba ustalić pojemność treściową stereotypu danego leksemu, która może sięgać do trojakiego rodzaju danych [Bartmiński, 1998, s. 66]:

1. Systemu językowego — utrwalonych form wyrazowych, frazemów zawierających komponent 'wielokulturowość' i reguł konstruowania znaków złożonych; najczęściej bada się definicje w różnych typach słowników: ogólnych języka polskiego, frazeologicznych, antonimów, synonimów, zwrotów bliskoznacznych etc.

2. Materiałów ankietowych — zbieranych według odpowiednio przygotowanego kwestionariusza; pozwalają one uzyskać obraz danego pojęcia w świadomości użytkowników języka, a zwłaszcza różnorakie konotacje.

3. Tekstów — wypowiedzi są zawsze intencjonalne i ukazują funkcjonawanie pojęcia w świadomości użytkowników języka, zarówno w warstwie znaczeń bezpośrednich, jak i pośrednich (w presupozycji).

Ze względów badawczych teksty nie będą jednak analizowane. Ograniczę się do przedstawienia definicji słownikowych i wyników ankiet.

Wyraz 'wielokulturowość' jest pojęciem młodym, które weszło do języka ogólnego ze specjalistycznego słownictwa nauk politologicznych. Sam leksem pod względem gramatycznym jest kompozycją (złożeniem), składającą się z dwóch tematów słowotwórczych: wiel- i kulturowość połączonych spójką (interfiksem) -o-. Ze względu na młody wiek badanego leksemu Słownik języka polskiego pod red. Witolda Doroszewskiego nie notuje badanego pojęcia [Doroszewski, 1958-1969]. Podobnie jest w Słowniku współczesnego języka polskiego pod red. Bogusława Dunaja [Dunaj, 2001]. W Słowniku języka polskiego PWN pod red. Mieczysława Szymczaka można odnaleźć jedynie wyraz 'wielonarodowościowy', czyli dotyczacy wielu lub kilku narodów; składający się z wielu lub kilku narodów [Szymczak, 1995, s. 657]. Również tylko leksem ‘wielonarodowościowy’ pojawia się w Innym słowniku języka polskiego 
pod red. Mirosława Bańki [Bańko, 2000]. Tylko jeden ogólny słownik języka polskiego odnotowuje badany przeze mnie wyraz, tj. Praktyczny słownik języka polskiego pod red. Haliny Zgółkowej. Można znaleźć tam informację, że 'wielokulturowość' jest wyrazem pochodnym od 'wielokulturowy' $\mathrm{i}$ jest terminem zaczerpniętym z nauk socjologicznych oraz kulturowych: zróżnicowanie kulturowe na danym terenie; występowanie obok siebie, przenikanie sie wielu kultur [Zgółkowa, 2004 (t. 45), s. 296]. Definicja ta oprócz parafrazy wskazuje na nieukniony proces wpływanie na siebie kultur występujących obok siebie. Taka sytuacja będzie uzasadniała językowy obraz tego pojecia w świadomości użytkowników języka. Słowniki frazeologiczne, antonimów, synonimów etc. nie notują badanego leksemu.

\section{Wyniki ankiety}

Grupa badawcza liczyła 100 osób. Ankieta przeprowadzona została wśród uczniów I Liceum Ogólnokształcącego im. T. Kościuszki w Łasku, studentów filologii polskiej Uniwersytetu Łódzkiego i słuchaczy Uniwersytetu Trzeciego Wieku w Łasku. Takie zróżnicowanie ankietowanych pozwala zapobiec ukierunkowaniu wyników na jedną grupę społeczną (np. miejską młodzież). Na stu ankietowanych siedemdziesięciu jeden mieszka w mieście do 50 tys. mieszkańców, dziewiętnastu jako miejsce zamieszkania zaznaczyło miasto powyżej 50 tys. mieszkańców, natomiast dziesięciu ankietowanych żyje na wsi. Ankieta powstała na bazie sposobu badania językowego obrazu świata, zaproponowanego przez Jerzego Bartminskiego [Bartmiński, 1998], ale ponadto została odpowiednio zmodyfikowana.

Część właściwą ankiety otwierało pytanie o zdefiniowanie słowa 'wielokulturowość'. 53 osoby uznały, że 'wielokulturowość' to różnorodność kulturowa/zróżnicowanie kulturowe wartsw społecznych, żyjacych obok siebie. 12 osób do podobnej definicji dodało różnorodność zwyczajów i zasad; 10 osób zwróciło uwagę na sprzeczność systemów normatywnych i poglądowych w mieszance etnicznej. Jest to niezwykle istotne - zwraca uwagę na spory i konflikty, jakie zachodzą wśród ludzi żyjących na danym obszarze a pochodzących z różnych kultur wskazuje to oczywiście na cechę stereotypową, ale bardzo ważną dla naszego badania, która będzie się pojawiać przy dalszych pytaniach. Kolejne 9 osób wskazało na proces przenikania się wielu kultur, współistniejących na danym terenie; 8. ankietowanych zwróciło uwagę na burzliwe procesy historyczne i polityczne, które doprowadziły do zaistnienia wielokulturowości na danym obszarze. Takie stwierdzenie nasuwa ciekawe konotacje: w świadomości zwykłych (nazywanych niekiedy przeciętnymi) użytkowników języka wielokulturowość nie jest sytuacją naturalną, a sztucznie wytworzoną sytuacją geopolityczną. Dana kultura izoluje się od innej, a procesy integracji czy przenikania się kultur są sytuacją wtórną wymuszoną czynnikami zewnętrznymi. Takie myślenie jest niepokojące, gdyż może być genezą myślenie nacjonalistycznego. Pięć osób uznało wielokulturowość za sytuację poznawania i stosowania obcych zwyczajów i obyczajów, także tych z innych środo- 
wisk (niekoniecznie kultur). 3 osoby podały nie podały żadnej definicji. Może być to spowodowane zbyt przejrzystą budową słowotwórczą i niechęcią do powielania podobnych słów lub brakiem umiejętności parafrazowania.

W następnym pytaniu respondenci mieli za zadanie wypisać skojarzenia z padanym leksemem. Wyniki były następujące (w nawiasach podaję liczbę osób, które wskazały daną odpowiedź; kilka osób mogło podać kilka odpowiedzi): z wieloma kulturami (50), z różnorodnościa (47), z tolerancja (43), ze zróżnicowaniem etnicznym (38), z zachowaniem własnych zwyczajów (31), z wielojęzycznościa (25), z rodzinami wielokulturowymi (17), z konfliktami (15), z umiejętnościa zachowania się w różnych społecznościach (13). Kolejne odpowiedzi dotyczyły kategoryzacji, tzn. wskazania konkretnych obszarów, na których występuje wielokulturowość: USA (10), Kanada (8), Niemcy (7), Turcja (5), Łódź (4). Wśród wymienionych skojarzeń większość skojarzeń była pozytywna lub neutralna. Wskazane zostały nawet korzyści wynikające dla ludzi, żyjących na obszarze wielokulturowym: znajomość języków obcych i umiejętność zachowania się w innych środowiskach. Tylko jedną odpowiedź (konflikty) można uznać za zdecydowanie negatywną.

Pytanie czwarte polegało na wskazaniu cech, jakimi odznacza się wielokulturowość. W kwestionariuszu do badania językowego obrazu świata stworzonym przez J. Bartmińskiego, pytanie to rozbite było na dwa: podanie cech typowych i prawdziwych. Ze względu na charakter prac (badane pojęcie jest bardzo młode i specjalistyczne) zdecydowałem się nie rozgraniczać tych pytań. Najczęęściej wskazywaną cechą wielokulturowości byla tolerancja (67 głosów). Jest to cecha niezwykle pozytywna i porządana na terenach wielokulturowych, ale tak jednoznaczne wskazywanie na tolerancję, które $\mathrm{w}$ wielu przypadkach podyktowane jest polityczną poprawnością ankietowanych, nasuwa skojarzenia $\mathrm{z}$ cechą przeciwną — brakiem tolerancji oraz konfliktami ${ }^{1}$. Drugą podawaną przez ankietowanych cechą było współistnienie i przenikanie sie kultur/wpływanie jednej kultury na drugą (52 głosy). Nie wiadomo jednak czy zjawisko to oceniane jest pozytywnie, neutralnie czy negatywnie. Wśród pozostałych cech znalazły się: synkretyzm (brak doprecyzowania jaki; 19 głosów), patriotyzm (17), altruizm (15), różnorodność/dwoistość/dychotomia (12), wielojęzyczność (11 głosów — cecha ta była jednak zawsze wskazywana przez studentów specjalizacji nauczania języka polskiego jako obcego, którzy są uwrażliwiani na zjawisko transferu językowego), konflikty (10), oryginalność/nietypowość (7), otwartość (6), wielobarwność (4). Wśród wskazanych cech, podobnie jak wcześniej, jedyną jednoznacznie negetywną cechą sa konflikty.

Kolejne pytanie dotyczyło podania synonimów do słowa 'wielokulturowość'. Aż 80 osób wskazało na różnorodność kulturową/pluralizm kulturowy. W tym przy-

${ }^{1}$ O politycznej poprawności ankietowanych i jej skutkach w badaniu językowego obrazu świata pisały Beata Grochala i Magdalena Wojenka-Karasek w artykule Nie taki cudzoziemic straszny... [w:] Teksty i podteksty w nauczaniu języka polskiego jako obcego - 3, pod red. Grochali B. i WojenkiKarasek M., Łódź 2011. 
padku konstrukcja syntetyczna została zastąpiona konstrukcją analityczną. 37 osób wskazało na wielonarodowośćlmiędzynarodowość, co stanowi dobre potwierdzenie dla definicji zawartych w słownikach. Niepokojące jest zastąpienie badanego terminu leksemem kosmopolityzm, który został wskazany przez 22 osoby. W tym przypadku zapewne wielokulturowość i kosmopolityzm są oceniane pejoratywnie, jako zjawiska antynacjonalistyczne.

Pytanie szóste dotyczyło wskazania antonimów do słowa 'wielokulturowość'. Okazało się, że aż 40 osób za antonim uznało wyrażenie kultura narodowa. Widać więc wyraźnie, że przez badanych Polaków wielokulturowość jest postrzegana jako zagrożenie dla kultury narodowej, a ta wraz z patriotyzmem, jak wykazały badania socjologów i językoznawców ${ }^{2}$, jest jedną z ważniejszych wartości dla Polaków. Choć z drugiej strony aż 33 osoby wskazały, że antonimami 'wielokulturowości' są chamstwo i rasizm. Zauważyć zatem można pewną tendencję w ścieraniu się wybranych ideologii politycznych. Poza tym 20 osób spośród ankietowanych nie wskazało żadnego antonimu, a 15 osób zastąpiło 'wielokulturowość' — 'monokulturowością'.

W następnym pytaniu ankiety należało przytoczyć dowcipy odnoszące się do padanej problematyki. Słownik pojęć i tekstów kultury podaje, iż żarty łamia na ogót tabu obyczajowe, środowiskowe, polityczne [Stownik pojęć..., 2002]. Piotr Kowalski dodaje:

żarty w potocznym obiegu nie zawsze, a nawet raczej bardzo rzadko, bywają specjalnie wyrafinowane i wysmakowane. Mają jednak zupełnie inny walor poznawczy: to im trzeba przyznać niezwykłe właściwości diagnostyczne. Śmiech, jaki mają wzbudzić, z całą swoją niebezpieczną ambiwalencją, żeby się pojawił, potrzebuje spełnienia pewnych warunków: śmiać się można $\mathrm{z}$ tego, co rozpoznawalne, co mocno osadzone w doświadczeniu opowiadających. Ryzykowna gra $\mathrm{z}$ autorytetami, niebezpieczne wchodzenie $\mathrm{w}$ pole, obwarowane potęgą tabu, bywa często dodatkowym elementem w konwersacji, dla której dynamiki momenty śmiechu są intermedium pożądanym. Diagnostyczna moc dowcipu tkwi m. in. w odwadze, z jaką żartujący podejmują tematy społecznie istotne, objęte nakazami dyskrecji, bądź nawet narzucające potrzebę respektowania konieczności ochrony wartości społecznie istotnych.

[Kowalski, 2004, s.101]

Przeważająca większość dowcipów to tzw. żarty o Polaku, Rusku i Niemcu (ew. Francuzie lub/i Amerykanie). Wiele z nich było obscenicznych, jak np.:

Idzą Rusek, Polak i Niemiec przez granice, spotykają diabła

— Jeżeli chcecie przejść, musicie sprawić, aby mój koń zaczął się śmiać — powiedział.

Idzie Niemiec z Ruskiem, robią głupie miny, ale nic. Podchodzi Polak, stoi kilka sekund koń zaczyna się śmiać.

Wracają Rusek, Polak i Niemiec zza granicy, znowu napotykają diabła.

— Jeżeli chcecie przejść musicie sprawić aby koń przestał się śmiać, bo od tamtego czasu ciągle się śmieje.

Idą Rusek i Niemiec, śpiewają jakieś smętne pioseneczki, ale nic. Podchodzi Polak, stoi kilka sekund — koń przestał się śmiać.

${ }^{2}$ Por. wyniki badań np. A. Jasińskiej-Kani (1988), A. Saksona (2001), J. Błuszkowskiego (2003). 
— Polak, jak Ty to zrobiłeś, powiedz mi — zapytał diabeł.

— W jedną stronę powiedziałem mu, że mam większego niż on, a w drugą mu pokazałem

— odpowiedział.

W tym przypadku wyeksponowany został spryt Polaka, jego pewność siebie oraz duma z dużego przyrodzenia, które doceniło nawet zwierzę. W analizowanych tekstach pozostałe narodowości nie zostały zdeprecjonowane, a wyeksponowano jedynie zalety Polaka, ale nie zawsze tak bywa. Ilustruje to chociażby kolejny dowcip:

Polak, Niemiec i Rusek lecieli samolotem przez Afrykę. W pewnym momencie zabrakło im paliwa, jednak jakimś cudem udało im się wylądować. Pech w tym, że wylądowali na samym środku Sahary. Wysiedli z samolotu i zaczynają iść przed siebie. Idą tak już kilka godzin, wyczerpani do reszty, a znikąd pomocy. W pewnej chwili dostrzegają wielbłąda dwugarbnego.

— To cud!! — krzyknęli i zaczynają biec co sił.

Dobiegają do zwierzęcia. Polak szybciutko wskakuje na pierwszego garba, Niemiec na drugiego, a Rusek pyta:

- A ja gdzie?

Na to Niemiec siedzący z tyłu podnosi ogon wielbłąda do góry i mówi:

- A ty, Sasza, do kabiny.

Rosjanin przedstawiony zostal jako człowiek naiwny, którego łatwo wykorzystać, bazując na jego niewiedzy. Stereotypowość przejawia się także w imieniu Rosjanina. Nasi wschodni sąsiedzi najczęściej w dowcipach dostają imię Iwan lub Sasza.

W niektórych tekstach pojawia się swoista solidarność pomiędzy Polakiem a Rosjaninem:

Jadą przez Syberię Polak, Rusek, Anglik i Francuz. Nagle zaatakowały ich wilki. Trzeba więc kogoś wyrzucić. Zatem wyrzucili Anglika. Wilki się najadły, ale za godzinę znowu to samo. Wyrzucili Francuza. Po kolejnej godzinie wilki wracają. Rusek w tym momencie wyciągnął kałacha i wymłócił wszystkie wilki. Polak pyta:

— To, po co ich wyrzuciliśmy?

Na to Rusek wyciąga flaszkę i mówi:

— No, coś ty? Litra na czterech?

W tym dowcipie wyeksponowane zostały stereotypowe wady obu narodów: pijaństwo i okrucieństwo.

Większość dowcipów ukazuje jednak Polaka jako osobę sprytną, mądrą, potrafiącą przechytrzyć nawet diabła. Bohaterami dowcipów są natomiast sąsiedzi Polaków lub przedstawiciele narodowości, z którymi Polska była związana politycznie, społecznie lub gospodarczo. Dowipy te jednak nie odnoszą się bezpośrednio do badanej problemtyki. Wskazują jedynie stereotypowe postrzeganie przez Polaków innych narodów. Tylko raz pojawił się dowcip odmiennego typu:

Patrol drogówki niemickiej zatrzymuje auto do kontroli. Policjant sprawdza prawko i mówi do kolegi: Patrz, Osama, jakie on ma dziwne nazwisko: Schmidt. 
Przedstawiona scenka ilustruje sytuację w Niemczech, gdzie coraz większą rolę odgrywa mniejszość muzułmańska (arabska), co niepokoi niektórych Niemców. Żart ilustruje skutki, jakie może mieć obecna polityka wobec tej mniejszości. Dowcip ma oczywiście wydzwięk nacjonalistyczny.

Najciekawsze odpowiedzi padały na pytanie ósme, w którym respondenci mieli wskazać konkretne obszary występowania wielokulturowości. 42 osoby wymieniły Paryż i Francję, gdzie ściera się wiele kultur (europejska, arabska etc.). 38 osób wskazało na Łódź w wieku XIX, wówczas przenikały się na tym terenie kultury żydowska, polska i niemiecka, czego świadectwem są dziś chociażby nazwy własne. Warto zaznaczyć, że Łódź podały osoby mieszkające lub studiujące w tym mieście — tylko jedna osoba z Uniwersytetu Trzeciego Wieku w Łasku wskazała na to miasto. 37 osób za obszar wielokulturowy uznało Niemcy, w których największą rolę odgrywa kultura niemiecka i napływowa muzułmańska. 35 razy wskazane zostały Stany Zjednoczone. Trzy osoby dopisały w nawiasie, że USA są przykładem wielokultrurowości pozytywnej/dobrej, co zapewne należy rozumieć, że są postrzegane jako obszar, na którym różne kultury żyją bezkonfliktowo, tolerują się. Wielka Brytania została wyróżniona 29 razy, ale 12 razy dopisane zostało wyjaśnienie, że respondent miał na myśli przenikanie się kultury brytyjskiej z napływową polską. Zjawisko to jest oczywiście spowodowane najnowszą falą emigracji Polaków i znane ankietowanym, którzy zetknęli sie z nim osobiści lub przynajmniej słyszeli od znajomych lub z mediów. Następnym obszarem według ankietowanych jest Kanada (12 głosów). Zastanawiające jest jednak to, że Kanada pojawiła się tylko wśród słuchaczy Uniwersytetu Trzeciego Wieku. Brak popularności Kanady, wśród pozostałych ankietowanych, i wiedzy o niej, mogą być spowodowany szczątkowymi informacjami o tym państwie w mediach, internecie i programach szkolnych. Pojedyncze odpowiedzi wskazywały poza tym na: Kaszuby (9), Śląsk (5), Mazury (4), Zelów (4), Lwów (2), Casablancę (1). Casablanca jest zapewne zdeterminowana przez film M. Curtiza z 1942 roku (miejsce to zostało wskazane przez słuchaczkę UTW w Łasku). W filmie tym wyraźnie widać współistnienie kultury marokańskiej, francuskiej i kultur uciekinierów z ogarniętej wojną Europy. Interesujące są pozostałe obszary: Kaszuby, Ślask, Mazury, Zelów i Lwów.

Sprawa odrębności kulturowej i językowej Kaszubów i Ślązaków jest ostatnio dość żywa. Głośna była niedawno sytuacja dubbingowania gwarą śląską telenoweli latynowskiej pt. Niewolnica Isaura. Status językowy tego obszaru jest źródłem sporu wielu badaczy. W polskiej literaturze naukowej dominuje pogląd, iż etnolekt śląski jest dialektem języka polskiego [Dejna, 1982; Skudrzykowa, 2002; Miodek, 1996]. Język śląski jako odrębny język klasyfikowali tylko niektórzy slawiści [Hentschel, 2001; Rostropowicz, 2004]. W Narodowym Spisie Powszechnym z 2002 roku ponad 56 tys. obywateli zadeklarowało śląski jako język domowy. Język śląski został zrejestrowany w Międzynarodowej Organizacji Językowej, gdzie przydzielono mu kod 
ISO: „szl”’. Widać zatem wyraźnie tendecję do autonomizacji kultury śląskiej przez jej członków. Pociaga to nawet dalsze konsekwencje: powstaje literatura w gwarze ślaskiej, której analiza pokazuje pewne różnice w postrzeganiu świata [Gaze, 2011].

Kaszubi natomiast doprowadzili do uznania ich języka za regionalny ${ }^{4}$. Obecnie w Polsce istnieje kilkadziesiąt szkół, w których dzieci uczą się kaszubskiego (ponad

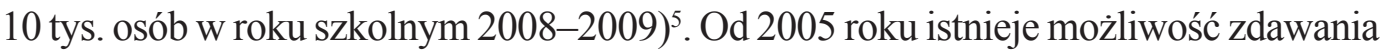
z niego egzaminu maturalnego ${ }^{6}$. W języku kaszubskim wydawane są książki i czasopisma [Mordawski, 2005, s. 62], emitowane są regionalne programy radiowe i telewizyjne [Tamże, s.76]. Po kszubsku jest też odprawiana liturgia słowa w kościołach.

Typowanie Mazur i Lwowa odwołuje się natomiast do wiedzy z histrii Polski. Mazury po II wojnie światowej zostały wcielone do Polski, co przyczynio się do interakcji między kultura polską (przede wszystkim katolicką), a protestancką kulturą niemieckojęzycznych Mazurów. Lwów zaś odsyła do tradycji II RP, kiedy to Polska była krajem wielonarodowym.

Pojawienie się Zelowa w odpowiedziach respondentów związane jest natomiast z faktem zamieszkania studentów UTW w Łasku, bo to oni właśnie wymienili to miasto $\mathrm{w}$ ankiecie. Zelów położony jest ok. $15 \mathrm{~km}$ od Łasku i zawsze był dla łaskowian przykładem miasta wielokulturowego, w którym schronienie znaleźli bracia czescy, uciekający przed prześladowaniami ze swojej ojczyzny. Żyją oni tu do dziś z katolikami z ziem powiatu łaskiego i bełchatowskiego. Podsumowując to pytanie, należy stwierdzić bardzo ważną rzecz: większość wskazywanych obszarów dotyczy Europy i Ameryki Północnej. W ani jednej ankiecie nie pojawił się obszar azjatycki, afrykański (wyjątkiem jest Casblanca), oceniczny czy z Amerki Południowej lub Środkowej. Socjologowie bardzo łatwo wythumaczyli takie zjawisko: posiadamy wiedzę tylko o bliskich sąsiadach lub o zjawiskach/postaciach/wydarzeniach, które są przekazywane przez najpopularniejsze media. Tych samych obszarów dotyczą także stereotypy Polaków. Zazwyczaj wskazywane obszary wielokulturowe pokrywały się z obszarami wielonarodowymi, co potwierdzają definicje słownikowe, które nie uwzględniają różnicy pomiędzy wielonarodowością, a wielokulturowością. Tylko kilka wskazań dotyczyło obszaru polskiego, a część z nich odnosiła się do przeszłości.

Dziewiąte pytania to „BUT TEST”. Jest to tekst do uzupełnienia, zasadzający się na modelu zdania przeciwstawnego. Wymaga on samodzielnego zwerbalizowania przez respondentów cech opozycyjnych wobec żywionych przez nich stereotypów, inaczej mówiąc — budowania zdań z presuponowanymi stereotypami. Wśród odpowiedzi pojawiły się:

3 SIL International Documentation for ISO 639 identifier: szl.

${ }^{4}$ Ustawa z dnia 6 stycznia 2005 r. o mniejszościach narodowych i etnicznych oraz o języku regionalnym: Dz. U. z 2005 r. Nr 17, poz. 141.

${ }^{5}$ http://www.kuratorium.gda.pl/index.php?c=347\&d=6064 [dostęp 25.09.2012].

${ }^{6}$ http://www.cke.edu.pl/podstrony/inform_matur/kaszubski.pdf [dostęp 25.09.2012]. 
$>$ rdzenni mieszkańcy nie akceptuja innych kultur (32) — wielokulturowość nie jest odbierana jako stan naturalny, a jako stan powstały w wyniku pocesów geopolitycznych i jest przyczyną konfliktów;

> jedna z kultur dominuje (24) - kultury współistniejące na jakimś terenie rywalizują o dominację na nim;

$>$ występuje rasizm (19) — konflikty są nieodłączną częścią obszarów wielokulturowych;

> brakuje jedności (18) — wielokulturowe społeczeństwo jest społeczeństwem zróżnicowanym, niezintegrowanym;

$>$ brak odpowiedzi (17).

W ostatnim pytaniu ankiety uczestnicy mieli wskazać artybuty - charakterystyczne przedmioty lub cechy wielokulturowości. Odpowiedzi były następujące: religia/-e (60 osób). Dla Polaków wielokulturowość równoznaczna jest z wyznawaniem przez inne narody innych religii. Potwierdzają to badania socjologów, według których Polacy charakteryzują siebie przede wszystkim jako katolików. Wśród pozostałych atrybutow znalazły się: zwyczaje (43), ubiór (36), taniec (29), melanż językowy (28 - termin ten znów został wskazany przede wszystkim przez studentów specjalizacji nauczania jpjo), potrawy (22), wywieranie wpływu na inne kultury/walka kultur (19 - jednoznacznie negatywne określenie), taniec (15), symbole (9 - brak dookreśleń), tolerancja (7), muzyka (3).

Reasumując, wyraz wielokulturowość, choć jest wyrazem młodym w polszczyźnie ogólnej, zawiera już pewien naddatek semantyczny. Przede wszystkim wielokulturowość postrzegana jest jako synonim wielonarodowości. Polacy raczej nie dpouszczają możliwości odniesienia tego pojęcia do sytuacji, kiedy to w ramach jednego narodu, można mówić o zróżnicowaniu kulturowych, wynikającym z rozmaitych czynników. Tylko nieliczni zauważyli obecność Kaszubów i Ślązaków. Jednakże nie wiadomo, czy ankietowani uznają przedstawicieli tych etnokultur za Polaków, czy też za Niemców, co niestety często sie zdarza. Kolejną, bardzo ważną kwestią, jest uznanie wielokulturowości za zajwisko negatywne, które powoduje erozję kultury narodowej (polskiej). Oprócz tego wielokulturowość kojarzona jest bardzo często z konfliktami, zatargami, wojnami. Przyczyna takiego stanu rzeczy jest moim zdaniem bardzo prosta: niewiedza, co pokazują wyniki jednego z pytań. Wśród terenów wielokulturowych wymieniane były tylko te leżące w Europie i Ameryce Północej, ankietwani nie wspomnieli (z niewiedzy?) ani razu o Ameryce Środkowej i Południowej, Azji, Afryce czy Oceanii. A wymieniane przez respondetów tereny były tematem wielu programów informacyjnych, bardzo często właśnie ze względu na konflikty na tych terenach. Brak wiedzy niejednokrotnie był przyczyną powstawania stereotypów. Należy mieć jednak nadzieję, że Polacy nie zamkną się na inne kultury, a ponadto będą pamietali o zróżnicowaniu kulturowym własnej ojczyzny. 


\section{Bibliografia}

BARTMiński J., 1998, Podstawy lingwistycznych badań nad stereotypem na przykładzie stereotypu matki [w:] Języka a kultura, Anusiewicz J., Bartmiński J. (red.), t. 12, Wrocław, s. 63-83.

BŁuszkowski J., 2003, Stereotypy narodowe w świadomości Polaków, Warszawa.

DEJNA K., 1982, Atlas polskich innowacji dialektalnych, Łódź.

GAZE M., 2011, Językowy obraz rodziny w etnokulturze Śląska Cieszyńskiego na przykładzie twórczości A. Wawrosza [w:] Bogactwo językowe i kulturowe Europy w oczach Polaków i cudzoziemców, Biernacka M., Wojenka-Karasek M. (red.), Łódź, s. 242-247.

Grochala B., WojenKa-Karasek M., 2011, Nie taki cudzoziemiec straszny... obraz cudzoziemca wśród studentów polonistyki $[\mathrm{w}]$ Teksty i podteksty w nauczaniu języka polskiego jako obcego — 3, Grochala B., Wojenka-Karasek M. (red.), Łódź, s. 335-343.

Hentschel G., 2001, Das Schleisische - eine neue (oder auch nich neue) slavische Sprache?, „Mitteleuropa-Osteuropa. Oldenburger Beitrage zur Kultur und Geschichte Ostmitteleuropas.” Band 2, s. 149-174.

Inny słownik języka polskiego, 2000, pod red. M. Bańko, Warszawa.

JASIŃSKA-KANIA A., 1988, Stereotypy narodowe w społeczeństwie polskim a opinie Polaków o różnych narodach i państwach. Konceptualizacja badań, cz. II, Warszawa. Kowalski P., 2004, Popkultura i humaniści. Daleki od kompletności remanent spraw, pogladów i mistyfikacji, Kraków.

SKUDRZYKowa A., 2002, Gwara ślaska - świadectwo kultury, narzędzie komunikacji, Katowice.

MiodeK J., 1996, Fenomen ślaskiej gwary, „Śląsk”, nr 5, s. 47-60.

Praktyczny słownik języka polskiego, 2004, pod red. Zgółkowej H., t. 45, Poznań.

Rostropowicz J., 2004, Ślaski byt jego językiem ojczystym. Reinhold Olesch, 1910-1990 [w:] Ślask bogaty różnorodnościa - kultur, narodów i wyznań. Historia lokalna na przykladzie wybranych powiatów, miast i gmin, Kluczniok K., Zając T. (red.), Czerwionka-Leszczyny, s. 47-54.

Sakson A., 2001, Polacy i Niemcy. Stereotypy i wzajemne postrzeganie, Poznań. Stownik języka polskiego, 1958-1969, pod red. Doroszewskiego W., t. 9, Warszawa. Stownik języka polskiego PWN, 1995, pod red. Szymczaka M., t. 3, Warszawa. Stownik pojęć i tekstów kultury, 2002, pod red. Szczęsna E., Warszawa. Słownik wspótczesnego języka polskiego, 2001, pod. red. Dunaja B., Warszawa. Ustawa z dnia 6 stycznia 2005 r. o mniejszościach narodowych i etnicznych oraz o języku regionalnym (Dz. U. Nr 17, poz. 141).

http://www.kuratorium.gda.pl/index.php?c=347\&d=6064 [dostęp 25.09.2012] http://www.cke.edu.pl/podstrony/inform_matur/kaszubski.pdf [dostęp 25.09.2012] 